University of Nebraska - Lincoln

DigitalCommons@University of Nebraska - Lincoln

\title{
The relationship between extent of hemoglobin purification and the performance characteristics of a blood-based flocculant
}

\author{
Rafael A. Garcia \\ USDA-ARS, rafael.garcia@ars.usda.gov \\ Lorelie P. Bumanlag \\ USDA-ARS, Lorelie.Bumanlag@ars.usda.gov \\ George J. Piazza \\ USDA-ARS, George.Piazza@ars.usda.gov
}

Follow this and additional works at: https://digitalcommons.unl.edu/usdaarsfacpub

\footnotetext{
Garcia, Rafael A.; Bumanlag, Lorelie P.; and Piazza, George J., "The relationship between extent of hemoglobin purification and the performance characteristics of a blood-based flocculant" (2017). Publications from USDA-ARS / UNL Faculty. 1805.

https://digitalcommons.unl.edu/usdaarsfacpub/1805
}

This Article is brought to you for free and open access by the U.S. Department of Agriculture: Agricultural Research Service, Lincoln, Nebraska at DigitalCommons@University of Nebraska - Lincoln. It has been accepted for inclusion in Publications from USDA-ARS / UNL Faculty by an authorized administrator of DigitalCommons@University of Nebraska - Lincoln. 


\title{
The relationship between extent of hemoglobin purification and the performance characteristics of a blood-based flocculant ${ }^{\dagger}$
}

\author{
Rafael A Garcia, ${ }^{*} \odot$ Lorelie P Bumanlag and George J Piazza๑
}

\begin{abstract}
BACKGROUND: Whole blood is a highly complex substance. Hemoglobin, the most abundant blood protein, can function as a flocculant; most of the other blood components exhibit poor flocculant activity. For the purpose of processing raw whole blood into a flocculant product, the practical value of hemoglobin purification is uncertain.

RESULTS: This study compares the flocculant performance of whole blood to that of three different semi-purified hemoglobin preparations. The whole blood is processed to remove the plasma proteins, the solid cell components, or both. The flocculant performance of whole blood and each hemoglobin preparation is compared over wide ranges of flocculant dose and suspension pH. The clarified liquids are examined for increases in chemical oxygen demand and Kjeldahl nitrogen. Hemoglobin preparations that excluded plasma gave peak flocculation performance at approximately $\mathbf{3 0} \mathbf{~ m g}$ solids per gram of suspended kaolin, and gave greatly reduced performance at higher doses; preparations that included plasma gave very similar peak performance, but also maintained relatively high performance at doses up to at least $200 \mathrm{mg} \mathrm{g}^{-1}$.
\end{abstract}

CONCLUSION: It is shown that removal of the plasma and the cell solids does not improve the flocculant performance or lessen the residual pollutants in the treated water.

Published 2017. This article is a U.S. Government work and is in the public domain in the USA.

Keywords: flocculant; processing; blood; water treatment; hemoglobin

\section{INTRODUCTION}

Blood is a by-product of meat production which is typically collected and processed to produce an animal feed ingredient. ${ }^{1}$ Recent research has demonstrated that blood and blood components can serve as bio-based substitutes for synthetic polymer flocculants such as polyacrylamide. Blood-based flocculants are highly effective at clarifying colloidal suspensions of kaolin clay ${ }^{2}$ and lignin. ${ }^{3}$

The blood of vertebrate animals is an exceedingly complex substance, but it is primarily red blood cells suspended in plasma. The red blood cells are essentially capsules containing a concentrated solution of hemoglobin $(\mathrm{Hb})$, which is by far the most abundant blood protein. ${ }^{4}$ The red cells of non-mammalian vertebrates, such as poultry species, also contain a nucleus. ${ }^{5}$ Plasma is an aqueous solution of many substances, predominantly the proteins serum albumin, various globulins and fibrinogen. ${ }^{6}$

Piazza et al. ${ }^{7}$ studied the most abundant blood proteins individually, in order to identify the components of blood responsible for its flocculation activity. $\mathrm{Hb}$ was found to have the greatest activity. Serum albumin, the second most abundant blood protein, did not display any flocculation activity. Particular plasma globulins displayed flocculation activity almost as high as $\mathrm{Hb}$, but they are present in much lower concentrations. Fibrinogen, which is typically about $4 \%$ of total plasma protein, had moderate flocculant activity.

Isolation of a relatively pure solution of $\mathrm{Hb}$ for use as a flocculant is not technically challenging. The red cells can be separated from the plasma by settling or centrifugation. The cells can then be lysed by physical or chemical means to release their contents. Finally, the solid cell debris, including the cell membrane and possibly the nuclei, can be removed by centrifugation or filtration.

It is not clear, however, that isolating $\mathrm{Hb}$ from the other blood components is actually advantageous. Compared to whole blood, $\mathrm{Hb}$ isolate may be a more potent flocculant because the less effective components are removed; indeed, a previous study ${ }^{8}$ compared bovine whole blood and commercially produced $\mathrm{Hb}$ and found that the $\mathrm{Hb}$ was more effective on a total solids basis. Also, removing components that do not have flocculant properties may minimize the amount of blood substances that remain in the treated water, contributing to undesirable wastewater characteristics such as turbidity, chemical oxygen demand (COD) and total Kjeldahl nitrogen (TKN). ${ }^{9}$ On the other hand, each unit operation

\footnotetext{
Correspondence to: RA Garcia, Biobased and Other Animal Co-products Research Unit, Eastern Regional Research Center, Agricultural Research Service, United States Department of Agriculture, 600 East Mermaid Lane, Wyndmoor, PA 19038, USA. E-mail: rafael.garcia@ars.usda.gov

$\dagger$ Mention of trade names or commercial products in this publication is solely for the purpose of providing specific information and does not imply recommendation or endorsement by the U.S. Department of Agriculture (USDA). USDA is an equal opportunity provider and employer.

Biobased and Other Animal Co-products Research Unit, Eastern Regional Research Center, ARS, USDA, Wyndmoor, PA, USA
} 
of an $\mathrm{Hb}$ isolation process contributes capital and operating costs, and any components removed from the blood, such as plasma, may have to be disposed of at a financial or environmental cost. The present study examines these tradeoffs and attempts to provide a rational basis for determining whether or not $\mathrm{Hb}$ should be isolated for the purpose of producing blood-based flocculant.

\section{EXPERIMENTAL}

\section{Source and collection of blood}

Chicken blood was collected on the slaughter line of a chicken processing plant as described previously. ${ }^{9}$ Briefly, blood from slaughtered birds flowed from neck incisions into plastic trays containing a concentrated solution of dipotassium ethylenediamineteteraacetic acid (EDTA), which inhibits coagulation and microbial activity $;^{10}$ the final concentration of EDTA in blood was $15 \mathrm{mmol} \mathrm{L}^{-1}$. The blood was filtered through a nylon mesh screen to exclude any large debris. This blood, treated with anticoagulant and filtered, will be referred to as whole blood.

\section{Preparation of flocculant product variants}

$\mathrm{Hb}$ isolate product was produced by subjecting whole blood to a series of three operations (Table 1, product variant E). To eliminate plasma, whole blood was centrifuged at $5000 \times g$ for $30 \mathrm{~min}$ in a swinging bucket rotor to pellet the cells; the supernatant plasma was drawn off and discarded. The pelleted cells were resuspended in isotonic saline and washed by repeatedly centrifuging, discarding the supernatant and resuspending in fresh saline. To rupture the cells and release the $\mathrm{Hb}$-rich cell contents, the cells were subjected to ultrasonic processing in $25 \mathrm{~mL}$ batches using an S-4000 ultrasonic liquid processor (Misonix, Farmingdale, NY, USA) fitted with a microtip probe and operating at $40 \%$ amplitude. The sonicator was programmed to run in $2 \mathrm{~s}$ intervals, with $2 \mathrm{~s}$ pauses between intervals, while incubating in an ice-water bath. To remove solid cell debris, the sonicated liquid was centrifuged at $17000 \times g$ for $10 \mathrm{~min}$; the supernatant cell content component was drawn off and saved.

Product variants were produced by omitting one or two of the processing steps (Table 1, product variants A, B and D). As a consequence of these process variations, each product variant retains a different combination of the components of the whole blood. Product variant $C$ was different from the others in that it was just plasma, and does not have any of the $\mathrm{Hb}$-rich cell contents; it was included to provide an additional point of comparison. Multiple aliquots of each product variant were stored frozen until use. Any particular aliquot was frozen and thawed only once.

\section{Analysis of product variants}

Hemoglobin $(\mathrm{Hb})$

$\mathrm{Hb}$ was quantified using a modern version of the cyanmethemoglobin method. ${ }^{11}$ Prepared Drabkin's reagent was obtained from Sigma (St Louis, MO, USA), and the assay was carried out according to the product literature. ${ }^{12}$ Cyanmethemoglobin standard was obtained from Stanbio Laboratory (Boerne, TX, USA). Five replicate determinations were conducted for each sample type.

\section{Total solids (TS)}

TS content of blood product variants was determined by oven drying of samples to constant mass. Analyses were replicated four times.
Table 1. Whole blood was processed in various ways to give product variants $\mathrm{A}-\mathrm{E}$. The variants differ in the particular blood components that have been retained in the product

\begin{tabular}{|c|c|c|c|c|c|c|}
\hline \multirow[b]{2}{*}{$\begin{array}{l}\text { Product } \\
\text { variant }\end{array}$} & \multicolumn{3}{|c|}{$\begin{array}{l}\text { Processing } \\
\text { applied }\end{array}$} & \multicolumn{3}{|c|}{$\begin{array}{l}\text { Blood components } \\
\text { in product }\end{array}$} \\
\hline & $\begin{array}{l}\text { Wash } \\
\text { cells }\end{array}$ & $\begin{array}{l}\text { Rupture } \\
\text { cells }\end{array}$ & $\begin{array}{l}\text { Centrifuge } \\
\text { solids }\end{array}$ & Plasma & $\begin{array}{c}\text { Cell } \\
\text { contents }\end{array}$ & $\begin{array}{l}\text { Cell } \\
\text { solids }\end{array}$ \\
\hline$A$ & & $x$ & & $x$ & $x$ & $x$ \\
\hline B & & $x$ & $x$ & $x$ & $x$ & \\
\hline$C$ & $x^{5}$ & & & $x$ & & \\
\hline$D$ & $x^{P}$ & $x$ & & & $x$ & $x$ \\
\hline E & $x^{P}$ & $x$ & $x$ & & $x$ & \\
\hline
\end{tabular}

\section{Flocculation effectiveness}

The flocculant effectiveness of the blood products was measured using a method developed and validated by this laboratory, ${ }^{13}$ with some variations. Briefly, fine kaolin clay is suspended in a buffer solution and the turbidity of this suspension is determined before and after flocculant treatment. The flocculant treatment involves adding flocculant to the suspension, subjecting the suspension to a controlled mixing program, followed by degassing of the suspension, and, finally, quiescent settling under temperature-controlled conditions. The initial turbidity $\left(T_{\mathrm{i}}\right)$ and final turbidity $\left(T_{\mathrm{f}}\right)$ of each vial is used to determine the kaolin clarification effectiveness (KCE) at each concentration, which is computed as follows:

$$
\mathrm{KCE}_{(\text {s.c. })}=\log _{10}\left(\frac{T_{\mathrm{i}}}{T_{\mathrm{f}}}\right)
$$

In the present study, small changes to the referenced method were adopted. In order to minimize the contribution of the suspension buffer to COD, the standard $25 \mathrm{mmol} \mathrm{L}^{-1}$ malic-MES-Tris (MMT) buffer was altered; in experiments with varying $\mathrm{pH}, 10 \mathrm{mmol}$ $\mathrm{L}^{-1} \mathrm{MMT}$ was used; in experiments with varying doses of blood product, $3 \mathrm{mmol} \mathrm{L}^{-1}$ malate buffer was used. All experiments used a kaolin concentration of $1 \mathrm{~g} \mathrm{~L}^{-1}$ rather than $3 \mathrm{~g} \mathrm{~L}^{-1}$, as this reduced interference with the analytical methods employed. All flocculant treatments were tested in quadruplicate.

\section{Analysis of treated suspensions}

Samples for chemical analysis of treated suspensions were drawn from $3 \mathrm{~cm}$ below the liquid surface using a pipette.

\section{Chemical oxygen demand}

COD was determined according to SM 5220 D. ${ }^{14}$ The analysis was conducted using pre-filled TNTplus COD reagent vials (Hach, Loveland, CO, USA) and a spectrophotometer specialized for this test format (model DR 3900, Hach). COD due to the suspension buffer was measured separately and this value was subtracted from the measured COD of treated suspensions.

\section{Total Kjeldahl nitrogen (TKN)}

TKN was determined using s-TKN test kits (Hach). These test kits, although they do not actually employ traditional Kjeldahl chemistry, are an EPA-accepted alternative for TKN determination. 
Table 2. Hemoglobin $(\mathrm{Hb})$ and total solids (TS) concentrations for product variants. Results are \pm 1 standard deviation. $\mathrm{Hb} / \mathrm{TS}$ is the mass ratio of $\mathrm{Hb}$ to TS; standard deviation of $\mathrm{Hb} / \mathrm{TS}$ was computed using an appropriate propagation of error formula

\begin{tabular}{lccc|} 
Product variant & $\mathrm{Hb}(\mathrm{mg} / \mathrm{mL})$ & $\mathrm{TS}(\mathrm{mg} / \mathrm{mL})$ & $\mathrm{Hb} / \mathrm{TS}$ b \\
\hline A & $97.3 \pm 2.0$ & $192.4 \pm 0.7$ & $0.51 \pm 0.01 \mathrm{a}$ \\
B & $99.8 \pm 3.8$ & $181.7 \pm 4.6$ & $0.55 \pm 0.03 \mathrm{a}$ \\
C & n.d. ${ }^{\mathrm{a}}$ & $84.6 \pm 3.2$ & \\
D & $91.8 \pm 2.6$ & $127.5 \pm 2.7$ & $0.72 \pm 0.03 \mathrm{~b}$ \\
E & $101.2 \pm 3.1$ & $116.6 \pm 1.6$ & $0.87 \pm 0.03 \mathrm{c}$ \\
\hline a None detected. & & \\
b Results followed by a common letter are not significantly different at \\
the 95\% confidence level. \\
\hline
\end{tabular}

\section{RESULTS AND DISCUSSION}

The blood product variants were intended to differ in composition due to the removal or retention of plasma and cell solids. Total solids is the concentration of all non-volatile dissolved and suspended substances in an aqueous liquid. The ratio of $\mathrm{Hb}$ concentration to TS ( $\mathrm{Hb} / \mathrm{TS})$ can be taken as a measure of the $\mathrm{Hb}$ purity in a product variant.

The variants without plasma ( $D$ and $E$ ) had much greater $\mathrm{Hb} / \mathrm{TS}$ than those in which plasma was retained ( $A$ and $B$ ) (Table 2). The variants without cell solids ( $B$ and $E$ ) had slightly greater $\mathrm{Hb} / \mathrm{TS}$ than their corresponding variants that retained cell solids ( $A$ and $D$, respectively), although the difference between $A$ and $B$ was not statistically significant. Variant $C$, which is simply plasma, did not have a detectable concentration of $\mathrm{Hb}$, as would be expected unless the red blood cells were lysing prematurely.

When added to a solution with suspended kaolin, each of the product variants caused some of the kaolin to flocculate, reducing the turbidity of the suspension. The $\mathrm{Hb}$-containing variants ( $A$, $B, D$ and $E)$, however, were much more effective than plasma (C) (Fig. 1a). Most of the reduction in turbidity occurred in the first hour after dosing with flocculant, and with further small reductions over at least the next $5 \mathrm{~h}$.

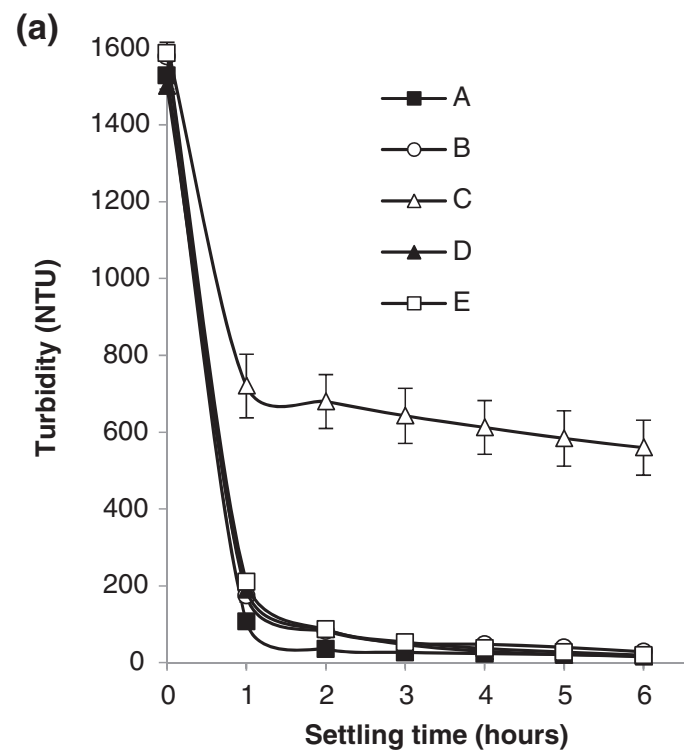

Comparing the effect of flocculants on a linear scale of turbidly has somewhat limited utility because in some applications very little turbidity is acceptable; in drinking water, for example, many jurisdictions have turbidity limits of 1-5 nephelometric turbidity units (NTU), and prefer to produce water that has about 0.1 NTU. The meaningful difference between 1 and 0.1 NTU is not clearly shown on a linear scale. Consequently, the remaining results are presented in terms of KCE, a logarithmic scale in which a result of 1 represents a $90 \%$ reduction in the initial turbidity, a result of 2 represents a $99 \%$ reduction, and so on. Replotting the settling time results in terms of KCE (Fig. $1 \mathrm{~b}$ ) shows that for the Hb-containing samples the settling that occurs after the initial hour results in an additional log-reduction in turbidity, a result that may be meaningful to end-users of the flocculant. Further, the KCE results are suggestive that the variants containing solid cell debris ( $A$ and $D$ ) clarify more rapidly that their counterpart solid-free variants ( $B$ and $\mathrm{E})$.

The dose dependence of KCE is quite different for the plasma-free ( $D$ and $E$ ) and plasma-containing ( $A$ and $B$ ) variants (Fig. 2). The plasma-free variants initially produced higher KCE with increasing dose up to a maximum, past which further increases in dose produced lower KCE. This is consistent with a known phenomenon observed when suspended particles are treated with a polymer. ${ }^{15}$ At low polymer concentration, the polymer covers only part of a particle's surface; polymer adsorbed on one particle can form a bridge between particles by adsorbing to a bare spot on another particle. At higher concentration, the polymer covers the entire particle surface, and steric interference inhibits coalescence of suspended particles.

The plasma-containing variants produced similar results at low doses, but markedly different results at higher doses. Higher doses produced KCE modestly lower than the peak KCE for these variants; the dose could be increased at least fourfold over the optimum dose without having a major negative impact on KCE. This result could be important in flocculant applications where the concentration of suspended particles is unknown or highly variable; suspensions could be overdosed with plasma-containing variants with little risk of flocculation failure.

(b)

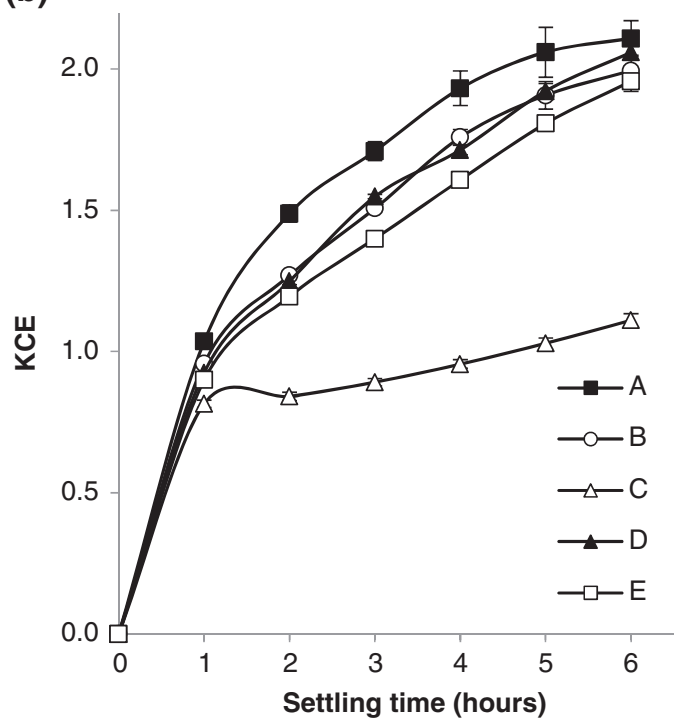

Figure 1. Clarification of a kaolin suspension over time, after being dosed with a blood flocculant product variant, in terms of (a) turbidity and (b) kaolin clarification effectiveness (KCE). Data points represent means of four replicate experiments and error bars represent \pm 1 standard deviation. 


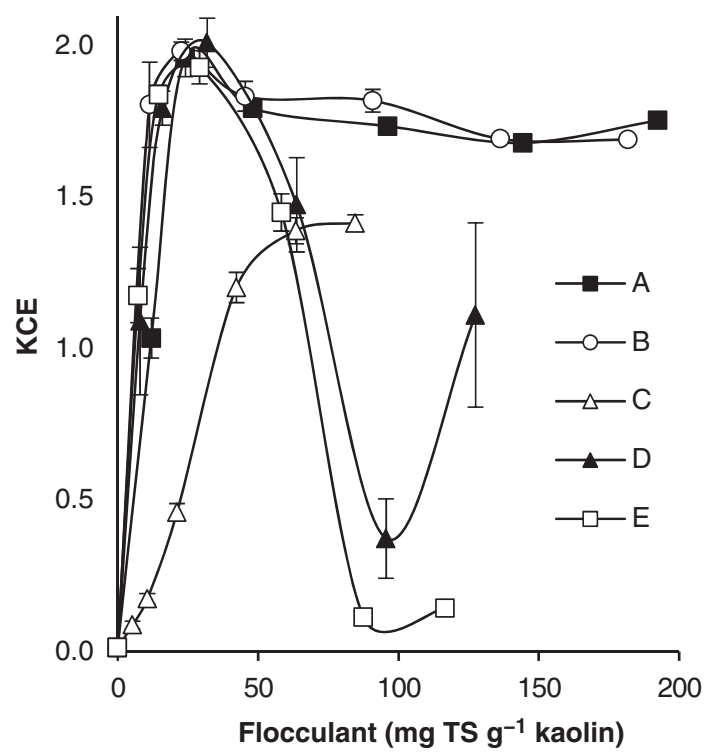

Figure 2. Kaolin clarification effectiveness (KCE) of flocculant product variants by flocculant dose at $6 \mathrm{~h}$ post treatment. Data points represent means of four replicate experiments and error bars represent \pm 1 standard deviation.

The reason for the difference in the KCE of plasma-containing and plasma-free variants is not clear. Plasma by itself (C) produces some flocculation at high doses. This may be due to the ionic strength of the plasma reducing the electrostatic repulsion between the kaolin particles, or it may be some phenomenon caused by the plasma proteins.

The previously reported decline in KCE for whole blood or $\mathrm{Hb}$ when used at $\mathrm{pH}$ greater that $5.5^{16}$ was mirrored in experiments using the product variants over a wide $\mathrm{pH}$ range (Fig. 3). This decline is thought to be related to a change in ionization state of $\mathrm{Hb}$ amino acid side chains, although this is not well understood. Hypothetically, the presence of plasma proteins with ionization characteristics different from $\mathrm{Hb}$ could mitigate this effect, allowing the product to be used at higher $\mathrm{pH}$. This turns out not to be the case. The performance of variant $\mathrm{C}$ declines more rapidly with $\mathrm{pH}$ compared to the $\mathrm{Hb}$-containing variants. The $\mathrm{pH}$ dependence of the $\mathrm{Hb}$-containing variants did not differ from one another in a systematic manner.

When added to a solution without suspended kaolin, the blood product variants all made substantial contributions to negative water quality characteristics, including turbidity, TKN and COD, even when used at the low levels that would be appropriate for a blood-based flocculant (Table 3). It was anticipated that product variants containing cell solids ( $A$ and $D)$ would contribute more turbidity than the corresponding solids-free variants ( $B$ and E), but the results do not support this. Rather, plasma seems to be responsible for more than half of the turbidity; both variants containing plasma ( $A$ and $B$ ) were much more turbid than those without plasma ( $D$ and $E$ ). Plasma-free variants ( $D$ and $E$ ) contributed much less to COD and TKN than their plasma-containing counterparts ( $A$ and $B$ ), as expected. Other important wastewater characteristics, including total suspended solids, total phosphate, fat oil and grease, and ammonia, were not measured; previous results ${ }^{9}$ indicate that whole blood would not contribute substantial concentrations of these pollutants when used in quantities relevant for the flocculant application. Whole blood and blood product variants are expected to make major contributions to

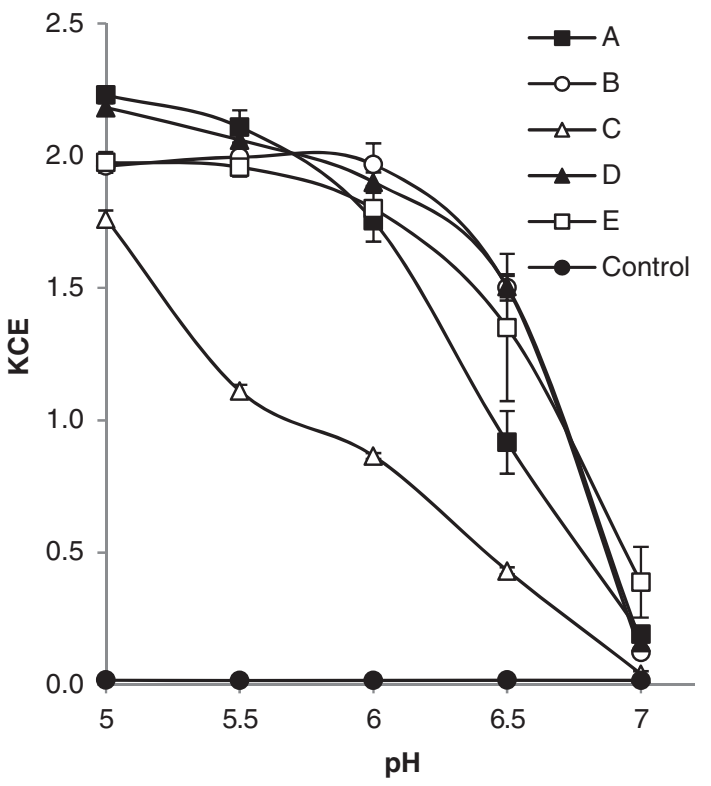

Figure 3. Effect of $\mathrm{pH}$ on kaolin clarification effectiveness (KCE) of product variants dosed at $50 \mathrm{mg} \mathrm{g}^{-1}$ kaolin and allowed to settle for $6 \mathrm{~h}$. Data points represent means of four replicate experiments and error bars represent \pm 1 standard deviation.

Table 3. Impact of adding $500 \mathrm{ppm}(\mathrm{v} / \mathrm{v})$ product variants on water quality in the absence of kaolin. Control is buffer with no added blood product. Chemical oxygen demand (COD) results are the difference between the measured value and the value for a control sample of buffer with no added blood product. Values are means \pm 1 standard deviation of 3-4 replicate experiments

\begin{tabular}{lccc|}
$\begin{array}{l}\text { Product } \\
\text { variant }\end{array}$ & $\begin{array}{c}\text { Turbidity } \\
(\mathrm{NTU})\end{array}$ & $\begin{array}{c}\mathrm{TKN} \\
\left(\mathrm{mg} \mathrm{L}^{-1}\right)\end{array}$ & $\begin{array}{c}\mathrm{COD} \\
\left(\mathrm{mg} \mathrm{L}^{-1}\right)\end{array}$ \\
\hline control & $0.3 \pm 0.2$ & $0.6 \pm 0.6$ & $0.0 \pm 1.8$ \\
A & $11.4 \pm 0.5$ & $11.6 \pm 0.2$ & $118.5 \pm 4.8$ \\
B & $15.0 \pm 2.0$ & $7.4 \pm 0.4$ & $117.2 \pm 3.4$ \\
C & $8.4 \pm 2.7$ & $2.3 \pm 0.2$ & $34.3 \pm 8.0$ \\
D & $5.5 \pm 2.9$ & $4.9 \pm 0.6$ & $70.7 \pm 4.0$ \\
E & $4.9 \pm 0.4$ & $6.7 \pm 0.7$ & $78.1 \pm 4.5$ \\
\hline
\end{tabular}

biochemical oxygen demand (BOD), which was not determined in this study; while BOD and COD are different, they are similar enough that it can reasonably be expected that, if BOD had been determined, the values would follow a pattern very similar to those found for COD.

When added to a kaolin suspension, the blood product variants may contribute TKN and COD to the clarified water remaining after solid particles are allowed to flocculate and settle. The results from testing both COD and TKN over a wide range of doses are very similar, suggesting that most of the COD in the product variants is due to protein (Fig. 4). In the dose range where all of the $\mathrm{Hb}$-containing variants gave high KCE results, approximately 15-60 mg TS $\mathrm{g}^{-1}$ kaolin, neither the COD nor the TKN of the clarified water was increased substantially. As described in the Methods section, the COD results reported are the difference between the measured COD and the COD of buffered suspension with no added flocculant; this accounts for the slightly negative COD reported, that is, no analysis actually produced a direct result that was a negative value for COD. At doses greater than 75 
(a)

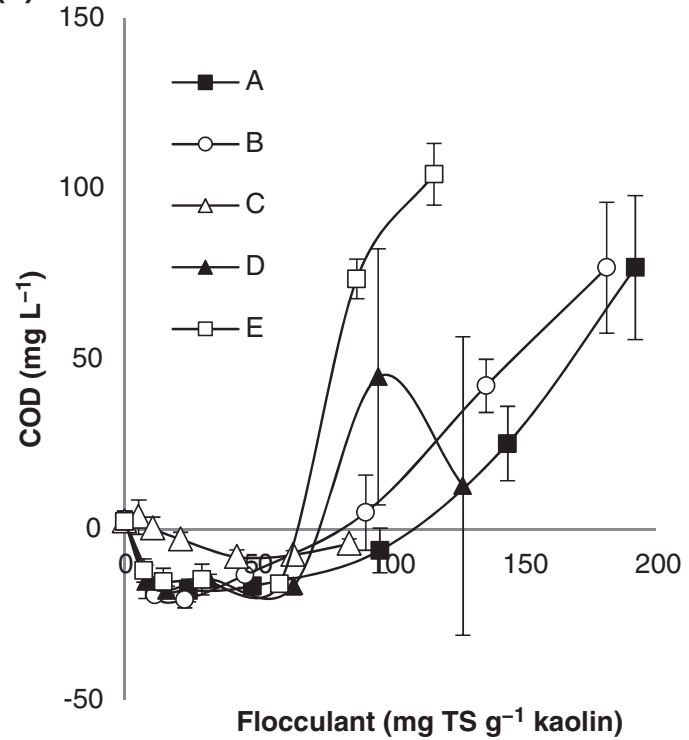

(b)

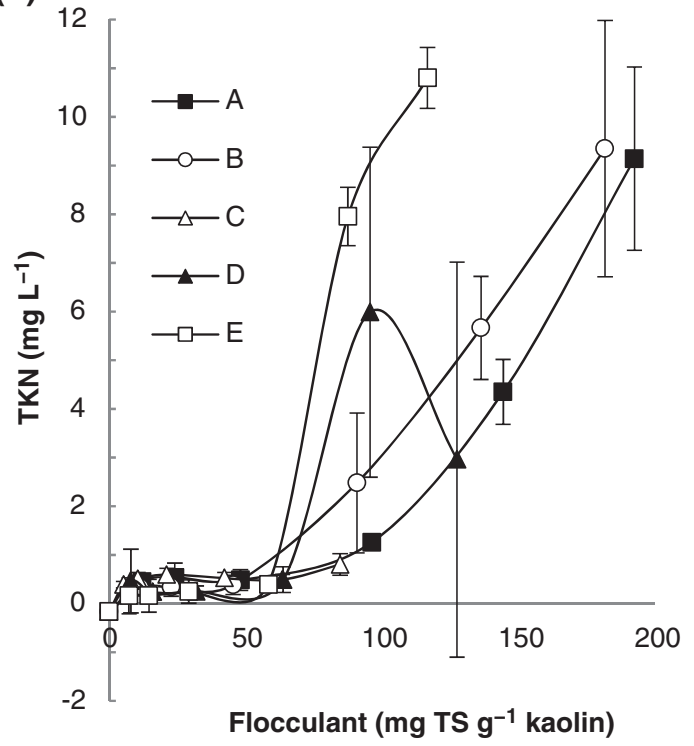

Figure 4. Dose of various flocculant product variants versus pollutant concentration of the treated suspension: (a) chemical oxygen demand (COD) and (b) total Kjeldahl nitrogen (TKN) were determined using samples taken from treated suspension $6 \mathrm{~h}$ post-flocculant dosing. COD values are corrected for buffer contribution to COD. Data points represent means of four replicate experiments and error bars represent \pm 1 standard deviation.

mg TS $\mathrm{g}^{-1}$ kaolin both the COD and TKN of treated water rise substantially. The data are suggestive of a more gradual increase in these values for plasma-containing variants ( $A$ and $B$ ), but the results from high product doses had too much variability to demonstrate this clearly.

\section{CONCLUSIONS}

Based on the aspects of flocculation performance examined in this study, there is no evidence that $\mathrm{Hb}$ is superior to whole blood. Rather, blood product variants containing plasma were much less sensitive to the negative effects of flocculant overdose. Inclusion of blood components other than $\mathrm{Hb}$ did not lead to excessive levels of pollutants.

Although this study did not examine processing costs, it is clear that the processing required to isolate $\mathrm{Hb}$ cannot be justified in terms of flocculant performance. Some issues unrelated to performance, and not examined in this study, may still be important to process design, including energy required to dehydrate each product variant, the impact of processing on pathogen inactivation or by-product disposal cost.

\section{REFERENCES}

1 Meeker DL and Hamilton CR, An overview of the rendering industry, in Essential Rendering, ed. by Meeker DL. National Renderers Association, Alexandria, VA, pp. 1-16 (2006).

2 Piazza GJ and Garcia RA, Proteins and peptides as renewable flocculants. Bioresour Technol 101:5759-5766 (2010).

3 Piazza GJ, Lora JH and Garcia RA, Flocculation of high purity wheat straw soda lignin. Bioresour Technol 152:548-551 (2014).

4 Schaller J, Gerber S, Kaempfer U, Lejon S and Trachsel C, Blood plasma proteins, in Human Blood Plasma Proteins: Structure and Function. Wiley, Chichester, pp. 17-20 (2008).
5 Colville TP and Bassert JM, Blood, lymph, and lymph nodes, in Clinical Anatomy and Physiology for Veterinary Technicians. Elsevier Health Sciences, Amsterdam, pp. 292-316 (2015).

6 Bah CS, Bekhit AE-DA, Carne A and Mcconnell MA, Composition and biological activities of slaughterhouse blood from red deer, sheep, pig and cattle. J Sci Food Agric 96:79-89 (2016).

7 Piazza GJ, Nuñez A and Garcia RA, Identification of highly active flocculant proteins in bovine blood. Appl Biochem Biotechnol 166:1203-1214 (2012).

8 Piazza GJ, Lora JH and Garcia RA, Flocculation of kaolin and lignin by bovine blood and hemoglobin. J Chem Technol Biotechnol 90:1419-1425 (2015).

9 Garcia RA, Nieman CM, Haylock RA, Rosentrater KA and Piazza GJ, The effect of chicken blood and its components on wastewater characteristics and sewage surcharges. Poultry Sci 95:1950-1956 (2016).

10 Garcia RA, Stein SD and Piazza GJ, Poultry blood preservation and the impact of preservation on flocculant activity. Appl Eng Agric 30:445-453 (2014)

11 Drabkin DL and Austin JH, Spectrophotometric studies. II. Preparations from washed blood cells: nitric oxide, hemoglobin and sulfhemoglobin. J Biol Chem 112:51-65 (1935).

12 Anonymous, Drabkin's reagent (Sigma product literature). SigmaAldrich, St. Louis, MO.

13 Garcia RA, Riner SA and Piazza GJ, Design of a laboratory method for rapid evaluation of experimental flocculants. Ind Eng Chem Res 53:880-886 (2014).

14 Eaton AD, Rice EW and Baird RB (eds), 5220 D chemical oxygen demand (COD), closed reflux, colorimetric method, in Standard Methods for the Examination of Water and Wastewater. American Public Health Association (APHA), American Water Works Association (AWWA), and the Water Environment Federation (WEF), Alexandria, VA (1998).

15 Hiemenz PC and Rajagopalan R, Polymer-colloid mixtures: a phenomologiocal perspective, in Principles of Colloid and Surface Chemistry (3rd edn). CRC Press, Boca Raton, FL, pp. 604-610 (1997).

16 Piazza GJ, McAloon AJ and Garcia RA, A renewable flocculant from a poultry slaughterhouse waste and preliminary estimate of production costs. Resour Conserv Recycl 55:842-848 (2011). 